\title{
THE EFFECT OF DRYING METHODS \\ ON THE PHYSICOCHEMICAL AND ANTIOXIDANT PROPERTIES OF BINTANGOR ORANGE (CITRUS NOBILIS) POWDERS
}

\author{
Pui Liew Phing ${ }^{1 凶}$, Aisyah Abdullah ${ }^{1}$, Chang Lee $\operatorname{Sin}^{2}$, Shalini Chan Yin Foong ${ }^{1}$ \\ ${ }^{1}$ Department of Food Science and Nutrition, Faculty of Applied Science, UCSI University \\ Jalan Puncak Menara Gading, 56000 Kuala Lumpur, Malaysia \\ ${ }^{2}$ Department of Food Sciences, Faculty of Science and Technology, Universiti Kebangsaan Malaysia \\ 43600 UKM Bangi, Selangor, Malaysia
}

\begin{abstract}
Background. Bintangor oranges are a mandarin species that is abundant in vitamin $\mathrm{C}$ and beta-carotene. However, due to its short shelf life, the fresh fruit can be converted into powder form, which is comparatively more stable.

Materials and methods. This study compares the effects of spray drying, freeze drying, drum drying, vacuum oven drying, and convection oven drying on the physicochemical properties of Bintangor orange powder, including vitamin $\mathrm{C}$ and total carotenoid content. The physicochemical properties analyzed for the powders were color analysis, moisture content, water activity, hygroscopicity, degree of caking, wettability, flowability, water solubility index, and bulk density.

Results. Our results showed that freeze dried and convection oven dried powders retained their color so that the powder was the same as the original puree. All powders used in this showed an acceptable moisture content level, with a range of 2.11-2.31\%. Spray dried and drum dried powders had the lowest value of moisture content and water activity. Moreover, spray dried powders showed the lowest value in hygroscopicity and bulk density and took the shortest time to wet the powder. The highest solubility and flowability properties were $12.99 \%, 0.39 \mathrm{~g} / \mathrm{mL}, 18.39 \mathrm{~s}, 96.08 \%$, and $19.17^{\circ}$, respectively. However, the freeze drying method retained the highest value for both nutritional pigments of vitamin $\mathrm{C}$ and total carotenoid content, $18.31 \mathrm{mg} / \mathrm{g}$ and $91.32 \mu \mathrm{g} / \mathrm{g}$, respectively.

Conclusion. Freeze drying is the most suitable drying method with favorable powder properties compared to spray drying, drum drying, vacuum oven drying and convection oven drying.
\end{abstract}

Keywords: Bintangor orange, spray drying, freeze drying, drum drying, vacuum oven drying, convection oven drying

\section{INTRODUCTION}

Bintangor orange is a species of mandarin originating in China and is known as Citrus nobilis. It is a hybrid between Citrus reticulata Blanco and Citrus aurantium L., which are common types of mandarin and bitter orange species. It is a perishable fresh commodity that has issues with long-term storage. This is due to its high moisture content which leads to nutrition loss due to microbial activity, rancidity, and browning (Sandarani et al., 2018). 
There are different techniques available to preserve fresh fruit using drying methods (Chauhan and Patil, 2013). The crucial principle and purpose of drying are to reduce water availability in a food product to prolong its shelf life by inhibiting microbial activity and enzymatic reactions (Sandarani et al., 2018). Additionally, drying can reduce the weight of packaging and the costs of transportation. Furthermore, it can also minimize the packaging requirements as it offers easier storage, reduced waste, and enhanced product quality.

Each drying method has unique characteristics that influence the drying rate, which maximizes water removal (Ergun et al., 2010). The freeze drying method is considered the best drying treatment because it preserves the natural color and maximum nutrients, as well as the original flavor and aroma, but it is also the most expensive method (Chew et al., 2019; Mahendran, 2008). Spray drying produced a stable powder at room temperature with a carrier, which reduced the stickiness and prevented caking. On the other hand, convective drying is considered to be the most common method of dehydration due to its low cost and an initial period of drying which is sufficiently efficient due to its high drying rates and large capacity. However, the color changed, i.e., the colour became dark because the long hours of exposure to high drying temperatures affects the organoleptic quality of the oven-dried powder (Gan et al., 2020). Hence, another drying method which is distinctive from oven drying, called vacuum oven drying, is applied to heat-sensitive substances (Wan Omar and Sarbon, 2016). However, the needs of the vacuum system result in high investments and operating costs, which is a downfall of this method that limits its application. Drum drying, on the other hand, is considered to be one of the most energy efficient drying methods due to its principle that allows food matrices to dry using a heated drum. A thin film of dry solids is obtained through short-term high temperature drying (Jittanit et al., 2011). Recent work on the production of spray dried Terung Asam, papaya, Kuini, cempedak, and pineapple powder has been reported (Chang et al., 2020b; Chang et al., 2020a; Loo and Pui, 2020; Pui et al., 2020a; Wong et al., 2015). Research has been done to compare the powders produced from different drying methods (Senphan et al., 2019).
This study determined and compared the effects of these five drying methods (spray drying, freeze drying, drum drying, vacuum oven drying, convection oven drying) on the physicochemical properties and antioxidant properties (ascorbic acid and total carotenoid contents) of Bintangor orange powder. These five drying methods were selected for study because they are commonly used and have significant design and operation parameters in food processing. Lastly, the best viable drying model among all the drying methods has been identified and recommended based on its ability to produce a high quality Bintangor orange powder.

\section{MATERIALS AND METHODS}

\section{Preparation of fruit samples}

The fruit used in this study was Bintangor orange. These oranges were purchased from a local hypermarket located in Cheras, Kuala Lumpur. The selected oranges were at commercial maturity (orange color), free from external defects and uniform in size, ranging from $6.0-6.5 \mathrm{~cm}$ in diameter. Three batches of samples were purchased.

\section{Preparation of fruit purees}

The Bintangor orange was peeled and deseeded. Juicing was carried out through a cheesecloth, and the mixture was mixed with maltodextrin $(50 \%)$ at a ratio of 1:5, with total soluble solids of $11^{\circ}$ Brix measured with a refractometer (Milwaukee, USA). Maltodextrin (DE $=10$, Bronson ad Jacobs, Australia) was incorporated constantly at $50 \%$ for different drying methods and to provide a thickener and preservative effect.

\section{Spray drying}

The spray drying process was conducted according to Chang et al. (2020b) with some modifications. Approximately $500 \mathrm{~g}$ of juice was weighed into a $500 \mathrm{~mL}$ beaker. Maltodextrin with a concentration of $50 \%$ $(\mathrm{w} / \mathrm{w})$ was added to the juice and homogenized using an electric homogenizer (IKA, Germany). The inlet temperature was set at $140^{\circ} \mathrm{C}$, with a nozzle speed and air compression of 5 and $40 \mathrm{~mm}$, respectively. Next, the nozzle pump was connected to a beaker of distilled water, which was then allowed to feed into the spray dryer (SD-05; Keison, United Kingdom) for around 15 min before spray drying. 


\section{Freeze drying}

The prepared fruit purees were added to aluminum trays that were covered with aluminum foil before being frozen and freeze dried. They were frozen to $-80^{\circ} \mathrm{C}$ in the freezer overnight. The frozen fruit purees were then freeze dried for $48 \mathrm{~h}$, at $-50^{\circ} \mathrm{C}$ in an ice condenser and a vacuum of $0.28 \mathrm{mbar}$ in the freeze dryer (Christ Alpha; John Morris group, Osterode, Germany). The final drying was set for $2 \mathrm{~h}$. After this, the freeze dried products were collected in airtight conditions through vacuum packaging for further analysis (Gopinatha et al., 2020).

\section{Drum drying}

The fruit puree was added to the drum dryer (with specifications of a $20 \mathrm{~cm}$ pool level depth and a $2 \mathrm{~cm}$ gap; R. Simon (Dryers) Ltd, Nottingham, England). The drum drying process was conducted with the rotation speed and drum clearance set at $0.75 \mathrm{rpm}$ and $0.245 \mathrm{~mm}$, respectively. The resulting flakes were then ground into a powder (Sharp Blender, Malaysia) before being stored in airtight conditions (Pua et al., 2010).

\section{Vacuum oven drying}

The fruit puree was spread on a baking tray with an average thickness of $1.5 \mathrm{~cm}$. The drying process was conducted in a vacuum oven (VD 23; Binder, Germany), with the temperature and pressure set at $70^{\circ} \mathrm{C}$ and $1 \mathrm{bar}$, respectively. After $24 \mathrm{~h}$, the dried flakes were ground into powder (Gopinatha et al., 2020).

\section{Convection oven drying}

The drying was conducted in an oven (Memmert, Germany) with the following settings: $0.13 \pm 0.06 \mathrm{~m} / \mathrm{s}$ air velocity, counter-current flow, and at $55 \pm 0.5^{\circ} \mathrm{C}$; Gopinatha et al., 2020). The puree was spread on a drying tray with a thickness of $3.2 \mathrm{~mm}$. The dried powder flakes were ground into powder and stored in airtight conditions through vacuum packaging until further analysis.

\section{Process yield}

The process yields of freeze dried, spray dried, drum dried, vacuum oven dried, and convection oven dried powders were determined using the equation below (Pua et al., 2010):

$$
\begin{gathered}
\text { Process } \\
\text { yield, } \%
\end{gathered}=\frac{\text { weight of dried powder, } g}{\text { weight of fruit puree, } g} \times 100 \%
$$

\section{Physicochemical analysis of the powders}

Color analysis. The color of the Bintangor orange powders was analyzed using a HunterLab's Colorimeter (ColorFlex, Ez Hunter Associate Laboratory, Inc, United States) coupled with EasyMatch QC-ER software. The color data was expressed in terms of $L^{*}$, $a^{*}$ and $b^{*}$, with $L^{*}$ indicating the luminosity of the sample, $a^{*}$ indicating the variation between red and green, and $b^{*}$ indicating the variation between yellow and blue (Pui et al., 2018).

Moisture content. The moisture content of the Bintangor orange powders was determined according to Jittanit et al. (2010) with some modifications. The aluminum plates were pre-dried in a convection oven at $105^{\circ} \mathrm{C}$ for $1 \mathrm{~h}$. Approximately $2 \mathrm{~g}$ of each powder was weighed into the pre-dried aluminum plates. Then, the powders were placed in the oven for drying $(24 \mathrm{~h}$, $105^{\circ} \mathrm{C}$ ). The moisture content of the powders was determined by using the equation below:

$$
\begin{gathered}
\begin{array}{c}
\text { Percent of } \\
\text { moisture } \\
\text { content, \% }
\end{array} \\
\text { weight of dry powder, } g
\end{gathered} \times 100 \%
$$

Water activity. The water activity of the Bintangor orange powders was determined using an Aqualab Pre Water Activity Meter (Meter Food, Novasina, Switzerland). The water activity meter was switched on for $30 \mathrm{~min}$ before the analysis to warm up the instruments. The sample cup was placed into the sample port of the water activity meter without a cover, and the water activity meter was allowed to start. The reading was collected after the water activity meter made a beeping sound (Pua et al., 2010).

Hygroscopicity. The hygroscopicity of the Bintangor orange powders was determined as described by Pui et al. (2020b) with some modifications. Saturated ammonium sulfate was prepared in the glass desiccator at room temperature. The weight of the $50 \mathrm{~mL}$ beakers was recorded before 2 grams of each powder was 
weighed. Each powder was added to 3 beakers. The beakers with the powders were placed into the glass desiccator. After 1 week, the powders were removed from the desiccator to be weighed. The hygroscopicity of the powders was calculated using the following equation:

$$
\begin{aligned}
& \text { weight of sample after } \\
& \text { a week, } g \text { - initial weight } \\
& \begin{array}{c}
\text { Hygrosco- } \\
\text { picity, } \\
\mathrm{g} / 100 \mathrm{~g}
\end{array}=\frac{\text { of sample, } \mathrm{g}}{\text { initial weight of sample, } \mathrm{g}} \times 100 \%
\end{aligned}
$$

Degree of caking. 5 grams of powder was weighed and put through a $500 \mu \mathrm{m}$ sieve. The powders were shaken constantly for 1 min during sieving, and the remaining powder that was still left in the sieve was recorded. Degree of caking was calculated using the equation below (Chang et al., 2020b):

$$
\begin{aligned}
& \text { Degree of } \\
& \text { caking, } \%
\end{aligned}=\frac{\begin{array}{c}
\text { weight of sample left } \\
\text { on sieve, } g
\end{array}}{\text { weight of sample used, } g} \times 100 \%
$$

Wettability. The wettability of the Bintangor orange powder was determined according to Chauhan and $\mathrm{Pa}$ til (2013). The time was recorded for how long it took for the powder to spread over the cloth in a $6 \mathrm{~cm}$ circle $(1 \mathrm{~g})$ and be completely wet in a $2.5 \mathrm{~cm}$ dish filled with distilled water.

Flowability. The flowability of the powders was performed by allowing $5 \mathrm{~g}$ of powder to be poured through a funnel $(2 \mathrm{~cm}$ above base; Loo and Pui, 2020). The diameter of the resulting heap was recorded where the flowability (expressed in angle of repose) was determined using the equation below:

$$
\begin{gathered}
\text { Angle of } \\
\text { repose }
\end{gathered}=\tan ^{-1}\left(\begin{array}{c}
\begin{array}{c}
\text { height of funnel } \\
\text { from base, } \mathrm{cm}
\end{array} \\
\begin{array}{c}
\text { radius of sample } \\
\text { on base, } \mathrm{cm}
\end{array}
\end{array}\right) \times 100 \%
$$

Water solubility index. The water solubility index of the powder was determined as described by Loo and Pui (2020). Approximately 1 gram of the powder was added to distilled water $(10 \mathrm{~mL})$. The centrifuge tube was shaken vigorously and incubated $\left(37^{\circ} \mathrm{C}, 30 \mathrm{~min}\right)$ in a water bath. The supernatant was collected, and the aluminum plates were allowed to dry in the oven at $105^{\circ} \mathrm{C}$ for $5 \mathrm{~h}$. The residues in the aluminum plates were then weighed. The water solubility index was then calculated using the equation below:

$$
\underset{\text { Water solubility }}{\text { index }(\mathrm{WSI})}=\frac{\text { weight } \text { of residue }}{\text { weight of powder }} \times 100 \%
$$

Bulk density. The bulk density of the Bintangor orange powders was measured according to Tonon et al. (2011) with some modifications. The powders (5 g) were added to a measuring cylinder $(20 \mathrm{~mL})$, and the volume of powder after tapping (5 times) was measured. Bulk density was expressed in grams per milliliter $(\mathrm{g} / \mathrm{mL})$.

$$
\begin{aligned}
& \text { Bulk density } \\
& (\mathrm{BD})
\end{aligned}=\frac{\text { weight of powder, } \mathrm{g}}{\text { volume of powder, } \mathrm{mL}} \times 100 \%
$$

\section{Antioxidant analysis of the powders}

Vitamin C content analysis. Bintangor powder $(5 \mathrm{~g})$ was added to distilled water $(150 \mathrm{~mL})$ and starch indicator $(1 \mathrm{~mL})$ before titration with an iodine solution. The amount of vitamin $\mathrm{C}$ was then calculated using the equation below (Sapei and Hwa, 2014):

$$
\frac{M_{1} V_{1}}{n_{1}}=\frac{M_{2} V_{2}}{n_{2}}
$$

where:

$$
\begin{aligned}
& M-\text { molar of } \mathrm{KIO}_{3}, \\
& V \text { - final volume in the conical flask, } \mathrm{mL}, \\
& n \text { - the number of moles, and where } 1 \text { mole of } \\
& \text { iodine is equal to } 3 \text { moles of ascorbic acid. }
\end{aligned}
$$

Total carotenoid content. The total carotenoid content of the Bintangor powder was determined according to Pui et al. (2020a). Three grams of powder were added to distilled water $(10 \mathrm{~mL})$ and left to stand for 30 min. Following this, cold acetone $(20 \mathrm{~mL})$ was added and incubated at $25^{\circ} \mathrm{C}$ for $15 \mathrm{~min}$. The sample solution underwent vacuum filtration where further extraction was conducted on the residues. The filtrate and $50 \mathrm{~mL}$ of petroleum ether was then placed in a separatory funnel for further extraction. Two layers of solution were formed, and the stopcock was opened to discard the 


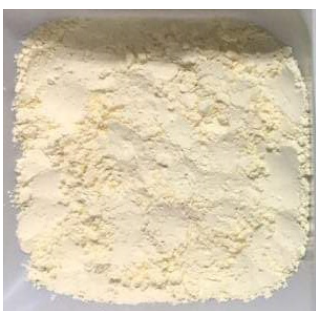

a

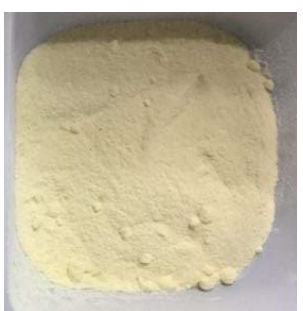

b

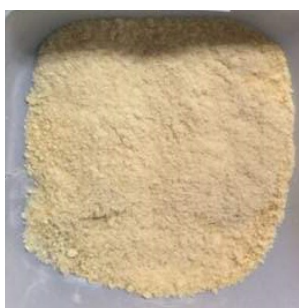

$\mathrm{C}$

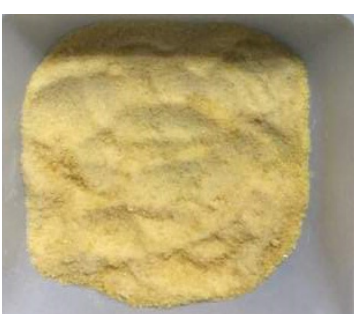

d

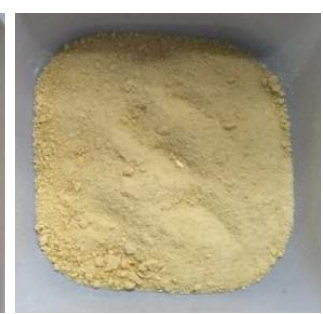

e

Fig. 1. Bintangor orange fruit powder processed using five different drying methods: $a$ - spray drying, $b$ - freeze drying, $\mathrm{c}$ - drum drying, $\mathrm{d}$ - vacuum oven drying, $\mathrm{e}$ - convection oven drying

bottom layer solution. The top layer solution in the separatory funnel was allowed to flow through anhydrous sodium sulfate $(15 \mathrm{~g})$. The filtrate collected was distilled off the petroleum ether using a rotary evaporator at $25^{\circ} \mathrm{C}$. The dried extract was then added to cold acetone $(1 \mathrm{~mL})$ before the absorbance was measured at $450 \mathrm{~nm}$ with a spectrophotometer (Uviline 9400, Secomam, France).

Statistical analysis. The analysis of the physicochemical properties and reconstitution properties of spray dried, freeze dried, drum dried, vacuum oven dried, and convection oven dried Bintangor orange powders was conducted triplicate $(n=3)$. SPSS (ver. 22) was used to conduct statistical analysis. A one-way ANOVA test and Tukey's test were performed to determine the significant differences $(p \leq 0.05)$.

\section{RESULT AND DISCUSSION}

\section{Process yield}

The Bintangor orange powders obtained through different drying methods are presented in Figure 1. Figure 2 shows the process yield of the spray dried, freeze dried, drum dried, vacuum oven dried, and convection oven dried powders. The process yields of spray dried, freeze dried, drum dried, vacuum oven dried and convection dried Bintangor powders were $21.11 \%$, $43.98 \%, 31.13 \%, 37.27 \%$, and $48.02 \%$, respectively (Fig. 2).

Figure 2 also shows that spray drying had the lowest yield among all the drying methods. This can be explained by the stickiness of the fine spray that the dried powder produced. The stickiness of the powder caused

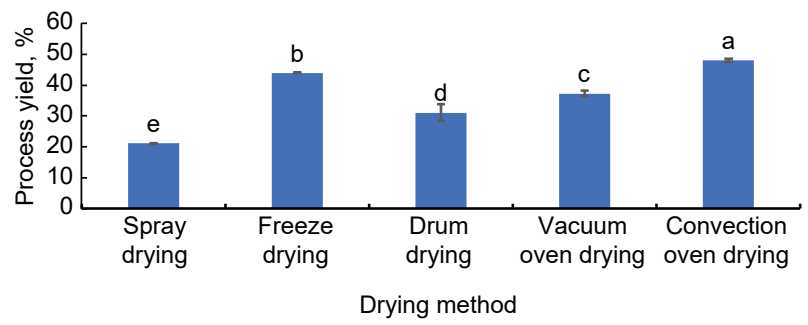

Fig. 2. Process yield of spray dried, freeze dried, drum dried, vacuum oven dried, and convection oven dried. Different letters a-e in the same column represents significances different at $p \leq 0.05$

cohesion of the powder to the surface of the spray dryer chamber. The presence of molecular weight sugars such as glucose, fructose, and organic acids is responsible for the fruits' stickiness (Chang et al., 2020b). These compounds have a low glass transition temperature and their hygroscopic nature causes the stickiness of dried fruits (Chang et al., 2018). Moreover, powder stickiness may cause blockages in the spray dryer system and reduce yields. In contrast, convection oven drying produces the highest yield, followed by freeze drying, vacuum oven, and drum drying methods.

\section{Physicochemical analysis of the powders}

Color analysis. The color of dried Bintangor orange powders is affected by the drying method (Mahendran, 2008). Figure 3 a shows that the $L^{*}$ value for Bintangor puree was 54.05 (Fig. 3a), while the spray dried, freeze dried, drum dried, vacuum oven dried and convection oven dried powders were 91.39, 73.70, 79.54, 79.72 , and 40.43 , respectively. In comparison to the 

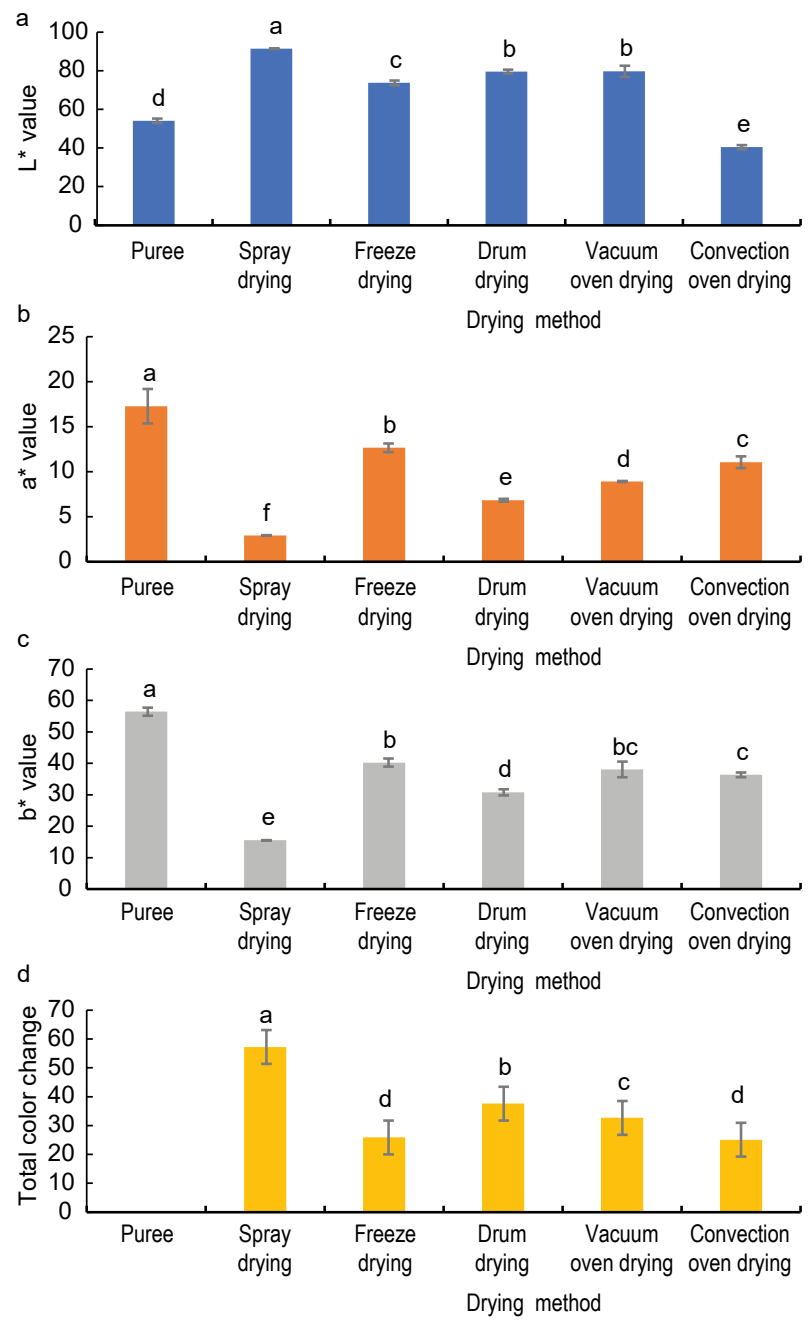

Fig. 3. Hunter color analysis $(L, a, b$ values and total color change) of Bintangor orange puree, as well as spray dried, freeze dried, drum dried, vacuum oven dried, and convection oven dried Bintangor orange powders. Different letters a-e in the same column represents significant differences at $p \leq 0.05$

fresh Bintangor puree (54.05), a significant increase in the $L^{*}$ value was observed with the exception of the convection oven dried Bintangor sample, which had a significantly lower $L^{*}$ value than the rest of the drying methods.

Among the different powders produced, spray dried Bintangor powder appeared to have the highest $L^{*}$ value, followed by drum dried, vacuum oven dried, and freeze dried. In contrast, convection oven
Bintangor powder had the lowest $L^{*}$ value. This indicates that spray dried Bintangor powder had the lightest color, while the convection oven Bintangor powder had the darkest color among all drying methods. The higher $L^{*}$ value of the spray dried Bintangor powder can be explained by the short drying time limiting color degradation. The lower $L^{*}$ value of convection oven Bintangor powder is probably due to the non-enzymatic browning reaction caused by certain chemical reactions including the deterioration of ascorbic acid. This leads to color degradation with prolonged exposure (Bharate and Bharate, 2014).

The $a^{*}$ value of fresh Bintangor puree was 17.27 and all dried Bintangor orange powder had a positive $a^{*}$ value, indicating that the powders were close to a red color (Fig. 3b). Jittanit et al. (2010) indicated that the positive $a^{*}$ value of freeze dried, drum dried, vacuum oven dried, and convection oven dried powders may be due to the browning reaction that occurred during the drying process. However, freeze dried Bintangor orange powder had the highest $a^{*}$ value, which was 12.66 , indicating that the powder was more reddish and closer to the original color of the puree (17.27). Devit et al. (2010) found that a low processing temperature retained the highest pigment content of vitamin $\mathrm{C}$ while simultaneously protecting the molecules responsible for the red color (Mahendran, 2008).

Bintangor orange puree is yellow in color, and the Bintangor puree (56.43) and Bintangor powder produced from all drying methods were 15.52, 40.23, $30.79,38.07$, and 36.33, respectively (Fig. 3c). They had positive $b^{*}$ values, indicating that they are more towards their original color. Spray dried Bintangor powder had the lowest $b^{*}$ value among all the powders, which was 15.52. Jittanit et al. (2010) stated that a low $b^{*}$ value may be caused by the high temperature of $140^{\circ} \mathrm{C}$ used during the spray drying, which was the highest among all drying methods, resulting in a less yellowish color. Moreover, the decrease in yellowness was also due to the oxidation of free radicals during drying. At the same time, the freeze dried powder had the highest $b^{*}$ value among all the powders due to its low processing temperature.

In terms of total color change, as seen in Figure 3d, it was found that freeze dried Bintangor orange powder had the smallest changes, while spray dried powder had the highest color changes, as the maltodextrin 
applied was white in color. Figures 4 and 5 illustrate the physicochemical results of spray dried, freeze dried, drum dried, vacuum oven dried, and convection oven dried Bintangor orange powders.

Moisture content. Figure 4a shows that the moisture contents of freeze dried, vacuum oven dried, and convection oven dried Bintangor powders are $2.30 \%$, $2.27 \%$, and $2.31 \%$ respectively, which display no significant differences $(p>0.05)$, while the moisture contents for spray dried and drum dried powders were $2.11 \%$ and $2.19 \%$, respectively. The value obtained from the study was lower than several reported studies in cempedak powders (6.07\%) (Pui et al., 2020a), papaya powder (5.21\%) (Chang et al., 2020b) and orange powder (Chegini and Ghobadian, 2015).

Spray dried Bintangor powder had the lowest moisture content as the drying temperature was $140^{\circ} \mathrm{C}$, followed by the drum dried Bintangor powder. With an increase in rotation speed, the moisture content of the powder also increased as the time that the feed stayed in the drum was reduced (Pua et al., 2010). Convection oven dried Bintangor powder had the highest moisture content as the drying temperature used was $45^{\circ} \mathrm{C}$, while for the freeze drying process, as the powder formed had a more porous structure, the moisture content was slightly higher. However, all the dried Bintangor orange powder was microbiologically stable since the range of moisture content was less than 4\% (Mahendran, 2008).

Water activity. Figure $4 \mathrm{~b}$ shows that the water activity of all the powders produced ranged from 0.171-0.241, which was in the range of powder water activity, according to Gobbetti et al. (2010). The spray dried and drum dried Bintangor orange powders had water activity of 0.171 and 0.190 , respectively, which were the lowest of the powders. This was due to the fact that the puree was heated at $120^{\circ} \mathrm{C}$ and $140^{\circ} \mathrm{C}$ for $48 \mathrm{~h}$ and several hours for drum drying and spray drying, respectively. Convection oven dried powder had the highest amount of water activity due to the low temperature used. In contrast, the second highest average values occurred with the freeze dried process, this is in agreement with results for apple juice powder and carrot powder, where a similar relation was also observed (Ergun et al., 2010). Microbial activity that

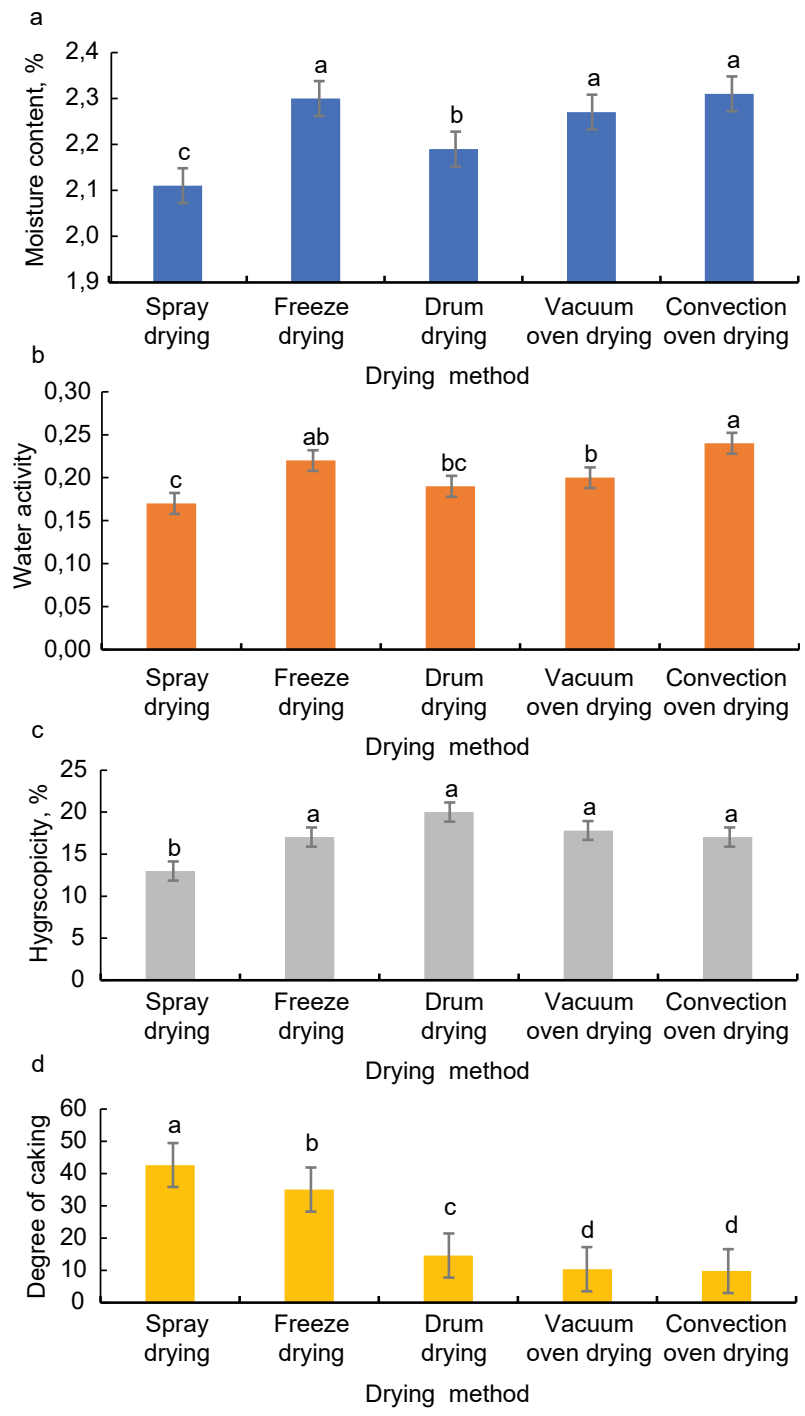

Fig. 4. Bintangor orange powders: a - moisture content, $\mathrm{b}$ - water activity, $\mathrm{c}$ - hygroscopicity, $\mathrm{d}$ - degree of caking. Different letters a-d in the same column represents significances different at $p \leq 0.05$

causes food deterioration was demonstrated as being inhibited because all the produced values were below 0.6 (Gobbetti et al., 2010).

Hygroscopicity. Chegini and Ghobadian (2015) and Moreira et al. (2009) reported that the percentages of hygroscopicity of powders are in the range of 3.28$34.72 \%$. Figure $4 \mathrm{c}$ shows that there was no significant 
difference $(p>0.05)$ in the hygroscopicity values of all the powders produced except for the spray dried Bintangor orange powder. These results reflect those of Chegini and Ghobadian (2015) who found that all Bintangor orange powders were hygroscopic with a percentage between $15.1-20 \%$. Drum dried powder had the highest percentage of hygroscopicity due to its higher absorbance of moisture from the environment as the product has a lower moisture content in processing conditions of a high temperature (Tonon et al., 2011). Spray dried Bintangor powder had the lowest percentage of hygroscopicity due to its high moisture content, which makes it unable to absorb moisture from the environment (Ergun et al., 2010).

Products that are sticky are more hygroscopic, hence the drying process should be conducted at a lower temperature than the glass transition temperature of its constituents (Chang et al., 2018). Furthermore, size is a reason for differences in hygroscopicity percentage. With particles that are smaller, the surface area is larger, which increases the active sites for interaction with air. However, maltodextrin, which is a well-known drying aid, helps resolve hygroscopicity problems (Tonon et al., 2011).

Degree of caking. Figure $4 d$ shows the degree of caking of spray dried, freeze dried, drum dried, vacuum oven dried and convection oven dried Bintangor orange powder, which was 42.62, 35.03, 14.56, 10.36 and 9.75 , respectively. The result obtained was in the range between $9.62-40 \%$, which is similar to a study done by Demirci et al. (2014) and Chegini and Ghobadian (2015), where convection oven dried was categorized as non-caking, while vacuum oven and drum dried were classified as slightly caking powders. Freeze dried and spray dried were classified as caking since the value was in the range between $20-50 \%$.

Based on Figure 4d, there is no significant difference $(p>0.05)$ between vacuum oven dried and convection oven dried powder. However, the degree of caking of spray dried powder was higher than the others because it was exposed to high humidity to produce a powder with high solubility. The relative humidity of the freeze dried environment was also high compared to other methods, which resulted in the second-highest value due to the temperature being $-50^{\circ} \mathrm{C}$, while the convection oven dried powder had the lowest degree of caking because the environment had a low humidity; therefore, it produced a powder with low solubility compared to spray dried and freeze dried powder.

Wettability. Figure 5a shows that the wettability of all the powders obtained from different drying methods was below $60 \mathrm{~s}$, which was also supported by Sunjka et al. (2014). Drum dried powder has the longest wettability time of 56.63, in comparison to the other drying methods. This may be due to a decrease in the powder moisture content of the drum dried powder (Chegini and Ghobadian, 2015). Spray dried powder had the shortest time of wettability. This indicates a good reconstitution of the properties of the powder obtained due to the small size of the beads that were produced by the spray drying apparatus (Lee et al., 2016). Schwartz and Lorenzo (2014) also stated that all dried powder had excellent properties with the powder being higher in carbohydrates than fats and proteins.

Flowability. Figure $5 \mathrm{~b}$ shows the flowability of the Bintangor orange powders, where they can be classified under free-flowing properties with a repose below 45 (Moreira et al., 2009). The flowability of the freeze dried Bintangor orange powder showed the lowest values of angle repose $\left(18.09^{\circ}\right)$, indicating the best flowability properties. This result is supported by Moreira et al. (2009), where the freeze dried product has more flowability, while convection oven dried has the weakest flowability. This may depend on the particle structure where it involves adhesion between particles.

Water solubility index. Figure $5 \mathrm{c}$ shows the water solubility index (WSI) of spray dried, freeze dried, drum dried, vacuum oven dried, and convection oven dried Bintangor orange powders, which were in the range between 39-91\%. The WSI of drum dried Bintangor orange powder (39.05\%) was lower than all the others. High temperature destroys the product surfaces and the pores which allow reconstitution (Chauhan and Patil, 2013).

Vacuum oven dried powder showed the second lowest WSI due to the high temperature used, which was $70^{\circ} \mathrm{C}$ for $24 \mathrm{~h}$. It had a lower value of WSI compared to the spray drying method because the duration 

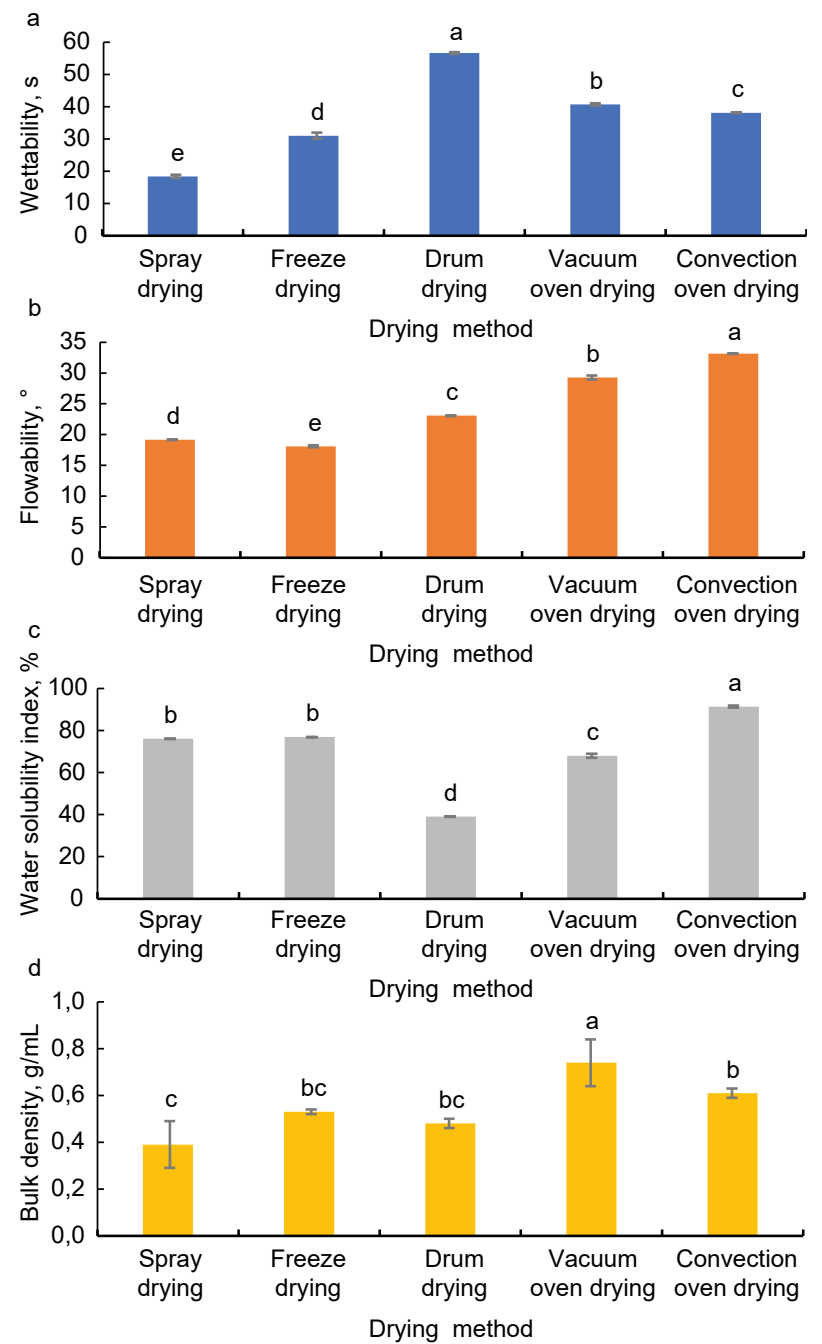

Fig. 5. Spray dried, freeze dried, drum dried, vacuum oven dried, and convection oven dried Bintangor orange powders: a - wettability, b - flowability, c - water solubility index, $\mathrm{d}-$ bulk density. Different letters a-e in the same column represents significances differences at $p \leq 0.05$

of heating was longer. The convection oven dried powder showed the highest WSI followed by the freeze dried powder due to the low temperatures applied which preserved the product surface and the pores that allowed water to enter into the sample and solubilize it. Moreover, the low temperature did not destroy any proteins present in the powder, which is responsible for the rate of solubility due to the presence of hydrophilic molecules (Devitt et al., 2010).
Bulk density. Figure $5 \mathrm{~d}$ showed that the bulk densities of the Bintangor orange powders were significantly different from each other $(p \leq 0.05)$, except for freeze dried, drum dried, and convection oven dried. The bulk densities of Bintangor orange powders produced from all drying methods ranged from $0.39-0.63$ $\mathrm{g} / \mathrm{mL}$. Spray dried Bintangor orange powder appeared to have the lowest bulk density compared to the others. This is due to its relationship to the inlet air temperature used, where the higher inlet air temperature caused faster evaporation, which made the powders more porous, while at the same time reducing their bulk density (Chang et al., 2020b).

Moreover, Chauhan and Patil (2013) reported that foods that underwent freeze drying had sublimation of ice in vacuum conditions. In this process, the ice changes to vapor without passing through the liquid state. This prevents shrinkage and the collapse of the product. A lower bulk density product was produced as it is more porous. The vacuum oven drying method had the highest bulk density because the powder is grainy in structure. In contrast, vacuum-dried powder, which is more crystalized in its form, has a less specific surface which gives less friction. Hence, the particles flow more easily and the powder becomes more compact and therefore density increases (Sogi et al., 2015).

\section{Antioxidant properties of the powders}

Vitamin C. Figure 6a illustrates the vitamin $\mathrm{C}$ content of Bintangor orange puree, as well as spray dried, freeze dried, drum dried, vacuum oven dried, and convection oven dried Bintangor orange powders. The vitamin $\mathrm{C}$ content of the Bintangor orange purees was originally high, with a value of $37.42 \mathrm{mg} / \mathrm{g}$. However, after drying the puree into a powder form, there was a decrease in vitamin $\mathrm{C}$ content in the spray dried, freeze dried, drum dried, vacuum oven dried, and convection oven dried Bintangor orange powder methods, where the yields were $15.03 \mathrm{mg} / \mathrm{g}, 28.31 \mathrm{mg} / \mathrm{g}, 13.72$ $\mathrm{mg} / \mathrm{g}, 18.10 \mathrm{mg} / \mathrm{g}$ and $24.36 \mathrm{mg} / \mathrm{g}$, respectively.

The total vitamin C content of freeze dried Bintangor orange powder was the highest followed by convection oven dried, vacuum oven dried, spray dried, and drum dried. The reduction in vitamin $\mathrm{C}$ after undergoing different drying treatments was in the range of $10-23 \mathrm{mg} / \mathrm{g}$. This is attributed to the lower 

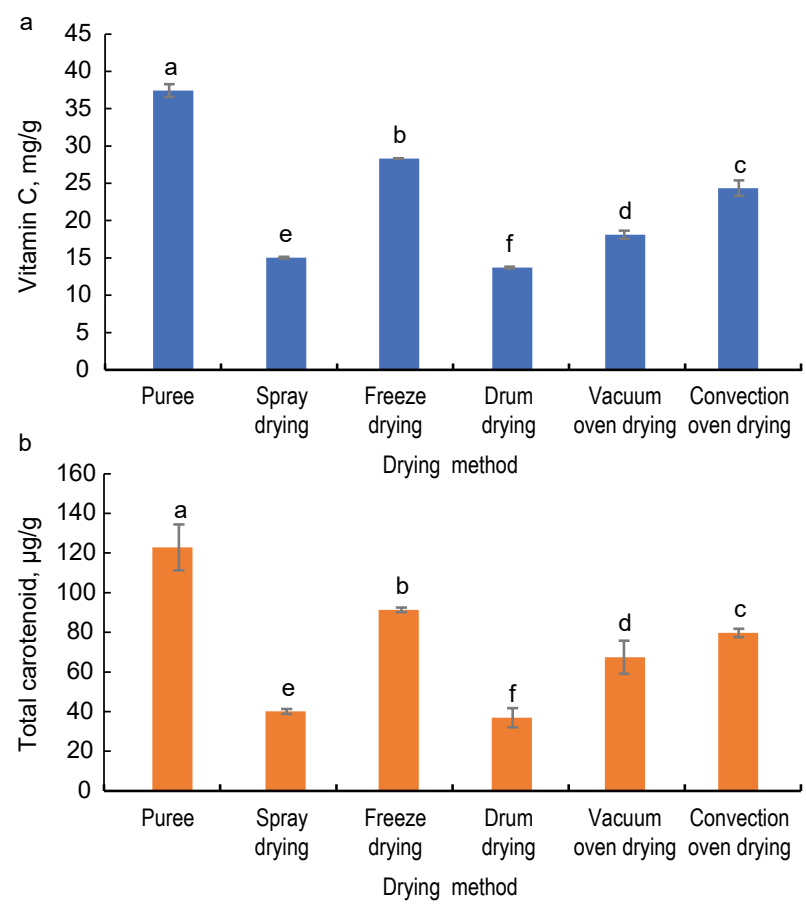

Fig. 6. Spray dried, freeze dried, drum dried, vacuum oven dried, and convection oven dried Bintangor orange powder: $\mathrm{a}$ - vitamin C, b - total carotenoid content. Different letters $\mathrm{a}-\mathrm{f}$ in the same column represents significant differences at $p \leq 0.05$

processing temperature applied in the freeze drying method. According to the results obtained, the freeze dried Bintangor orange sample was able to retain the most vitamin C, which was $76 \%$.

Lee et al. (2016) showed similar results, finding that the freeze dried tomato powder had a higher level of ascorbic acid, around $78.5 \%$, than spray dried and drum dried powder. In their work, the oxidative loss of ascorbic acid during vacuum drying was $31.3 \%$, which was higher than freeze drying $(21.5 \%)$ and spray drying $(25.8 \%)$. The high temperatures and oxidation involved in these reactions degrades ascorbic acid. The lowest vitamin $\mathrm{C}$ content in drum dried powder was due to easy evaporation at high temperatures because vitamin $\mathrm{C}$ is a heat-sensitive pigment (Pua et al., 2010). The usage of nitrogen gas applied during the freeze drying treatment can reduce oxidation (Mahendran, 2008).
Total carotenoid content. Figure $6 \mathrm{~b}$ shows that the total carotenoid content of Bintangor orange puree $(122.83 \mu \mathrm{g} / \mathrm{g})$ was originally high. However, after drying the purees into powder, the total carotenoid content in the spray dried, freeze dried, drum dried, vacuum oven dried and convection oven dried Bintangor orange powders decreased drastically to 40.08 $\mu \mathrm{g} / \mathrm{g}, 91.32 \mu \mathrm{g} / \mathrm{g}, 36.90 \mu \mathrm{g} / \mathrm{g}, 67.41 \mu \mathrm{g} / \mathrm{g}$, and 79.70 $\mu \mathrm{g} / \mathrm{g}$, respectively. The reduction in total carotenoid content after undergoing different drying treatments was in the range of $30-80 \mu \mathrm{g} / \mathrm{g}$.

As shown in the results obtained, the freeze dried Bintangor orange powder was able to retain the most total carotenoid of around $74 \%$, while the drum dried powder only retained around $30 \%$. The total carotenoid content of the freeze dried powder was higher than the other drying methods, followed by convection oven, vacuum oven, spray drying, and drum drying due to the moderate and lowest temperatures being applied and the possibility to perform rehydration at any desired level.

The total carotenoid content of convection oven dried powder was higher than the vacuum oven dried, spray dried, and drum dried powder. This is attributable to the low oven drying temperature applied (Sunjka et al., 2014). The lowest total carotenoid content in drum dried powder may be due to their higher processing temperature and stickiness of the fruit itself. This leads to powder accumulation on the drum wall, which leads to further oxidation (Demirci et al., 2014). Moreover, drum dried powder showed the least amount of total carotenoid since the drying conditions applied were at high temperatures for a longer time (Pua et al., 2010). Bigger losses in pigment and vitamin $\mathrm{C}$ content in the drum drying of cassava, cowpea and Africa spinach were also reported (Schwartz and Lorenzo, 2014).

\section{CONCLUSION}

Overall, the results showed that freeze dried Bintangor orange powder was the optimum method when compared to spray drying, drum drying, vacuum oven drying, and convection oven drying methods. The freeze dried powder retained a color similar to the original puree. The moisture content and water activity for all dried powders fell into an acceptable range to inhibit the growth of microorganisms. Furthermore, freeze 
Phing, P. L., Abdullah, A., Lee Sin, Ch., Yin Foong, S. Ch. (2022). The effect of drying methods on the physicochemical and antioxidant properties of Bintangor orange (Citrus nobilis) powders. Acta Sci. Pol. Technol. Aliment., 21(1), 111-122. http://dx.doi. org/10.17306/J.AFS.2022.0901

dried Bintangor orange powder had better wettability properties. Despite being slightly higher in the degree of caking and hygroscopicity, it was also more soluble than the other dried powders. Lastly, for antioxidant property analysis, the freeze dried powder retained a higher quantity of vitamin $\mathrm{C}$ and total carotenoid content compared to the other dried powders. The results of this study indicate that the freeze dried treatment is the most suitable and desirable method to preserve the maximum physicochemical and antioxidant properties of Bintangor orange powders. The orange powder produced from this study had a high stability with wellretained quality, which means that it can be applied in the food industry as a functional ingredient in food products such as beverages, jams and, baked goods.

\section{REFERENCES}

Bharate, S. S., Bharate, S. B. (2014). Non-enzymatic browning in citrus juice: chemical markers, their detection and ways to improve product quality. J. Food Sci. Technol., 51(10), 2271-2288. https://doi.org/10.1007/s13197012-0718-8

Chang, L. S., Karim, R., Abdulkarim, S. M., Yusof, Y. A., Ghazali, H. M. (2018). Storage stability, color kinetics and morphology of spray-dried soursop (Annona muricata L.) powder: Effect of anticaking agents. I. J. Food Prop., 21(1), 1937-1954.

Chang, L. S., Tan, Y. L., Pui, L. P. (2020b). Production of spray dried enzyme-liquefied papaya (Carica papaya L.) powder. Braz. J. Food Technol., 23, e2019181. http:// dx.doi.org/10.1590/1981-6723.18119

Chang, L. S., Yong, S. M. E., Pui, L. P. (2020a). Production of spray dried "Terung Asam" (Solanum lasiocarpum Dunal) powder. Walailak J. Sci. Technol. (WJST), 18, 1.

Chauhan, A. K., Patil, V. (2013). Effect of packaging material on storage ability of mango milk powder and the quality of reconstituted mango milk drink. Powder Technol., 239, 86-93. https://doi.org/10.1016/j.powtec.2013.01.055

Chegini, G. R., Ghobadian, B. (2015). Effect of spray drying conditions on physical properties of orange juice powder. Drying Technol., 23(3), 657-668.

Chew, S., Tan, C., Pui, L., Chong, P., Gunasekaran, B., Nyam, K. (2019). Encapsulation technologies: A tool for functional foods development. ITIJEE, 8(5S), 154-160.

Demirci, Z. O., Y1lmaz, I., Demirci, A. S. (2014). Effects of xanthan, guar, carrageenan and locust bean gum addition on physical, chemical and sensory properties of meatballs. J. Food Sci. Technol., 51(5), 936-942. https:// doi.org/10.1007/s13197-011-0588-5

Devitt, L. C., Fanning, K., Dietzgen, R. G., Holton, T. A. (2010). Isolation and functional characterization of a lycopene beta-cyclase gene that controls fruit colour of papaya (Carica papaya L.). J. Exp. Bot., 61(1), 33-39. https://doi.org/10.1093/jxb/erp284

Ergun, R., Lietha, R., Hartel, R. (2010). Moisture and shelf life in sugar confections. Crit. Rev. Food Sci. Nutr., 50(2), 162-192. https://doi.org/10.1080/10408390802248833

Gan, J. Y., Chang, L. S., Mat Nasir, N. A., Babji, A. S., Lim, S. J. (2020). Evaluation of physicochemical properties, amino acid profile and bioactivities of edible bird's nest hydrolysate as affected by drying methods. LWT - Food Sci Technol., 131(July), 109777.

Gobbetti, M., Cagno, R. D., de Angelis, M. (2010). Functional microorganisms for functional food quality. Crit. Rev. Food Sci. Nutr., 50(8), 716-727. https://doi.org/10. 1080/10408398.2010.499770

Gopinathan, M., Yusof, Y. A., Pui, L. P. (2020). Effects of different drying methods on the physicochemical and antioxidant content of 'cempedak' (Artocarpus integer L.) powder. J. Food Proc. Preserv., 44, 12. https://doi. org/10.1111/jfpp.14966

Jittanit, Q., Niti-Att, S., Techanuntachaikul, O. (2010). Study of spray drying of pineapple juice using maltodextrin as an adjunct. Chiang Mai J. Sci., 37(3), 498-506.

Jittanit, W., Chantara-In, M., Deying, T., Ratanavong, W. (2011). Production of tamarind powder by drum dryer using maltodextrin and arabic gum as adjuncts. Songklanakarin J. Sci. Technol., 33(1), 33-41.

Lee, S. H., Park, J. G., Lee, D. Y., Kandpal, L. M., Jun, S. (2016). Drying characteristics of agricultural products under different drying methods: A review. Biosyst. Eng., 41(4), 389-395. https://doi.org/10.5307/ JBE.2016.41.4.389

Loo, Y. Y., Pui, L. P. (2020). Storage stability of kuini (Mangifera odorata) powder in aluminum laminated polyethylene and polyethylene terephthalate. Malaysian J. Anal. Sci., 24(5), 657-669.

Mahendran, T. (2008). Effects of drying methods on the quality characteristics of mango powder. Food Sci. Technol. (Campinas), 5(9), 16-47.

Moreira, G., Maia Costa, M., Souza, A., Brito, E., Medeiros, M., Azeredo, H. (2009). Physical properties of spray dried acerola pomace extract as affected by temperature and drying aids. LWT - Food Sci. Technol., 42(2), 641645. https://doi.org/10.1016/j.lwt.2008.07.008 
Phing, P. L., Abdullah, A., Lee Sin, Ch., Yin Foong, S. Ch. (2022). The effect of drying methods on the physicochemical and antioxidant properties of Bintangor orange (Citrus nobilis) powders. Acta Sci. Pol. Technol. Aliment., 21(1), 111-122. http://dx.doi. org/10.17306/J.AFS.2022.0901

Pua, C., Hamid, N., Tan, C., Mirhosseini, H., Rahman, R., Rusul, G. (2010). Optimization of drum drying processing parameters for production of jackfruit (Artocarpus heterophyllus) powder using response surface methodology. LWT - Food Sci. Technol., 43(2), 343-349. https://doi.org/10.1016/j.lwt.2009.08.011

Pui, L. P., Karim, R., Yusof, Y. A., Wong, C. W., Ghazali, H. M. (2020a). Optimization of spray drying parameters for the production of 'Cempedak' (Artocarpus integer) fruit powder. J. Food Meas. Charact., 14, 3238-3249. https:// doi.org/10.1007/s11694-020-00565-3

Pui, L. P., Karim, R., Yusof, Y. A., Wong, C. W., Ghazali, H. M. (2018). Physicochemical and sensory properties of selected 'cempedak' (Artocarpus integer L.) fruit varieties. Int. Food Res. J., 25(2), 861-869.

Pui, L. P., Karim, R., Yusof, Y. A., Wong, C. W., Ghazali, H. M. (2020b). Anti-caking agent effects on the properties of spray-dried 'Cempedak' fruit powder. J. Trop. Agric., 43(4), 621-635.

Sandarani, M. D. J. C., Dasanayaka, D. C. M., Jayasinghe, C. V. L. (2018). Strategies used to prolong the shelf life of fresh commodities. J. Sci. Food Agric., 9(1), 206-219.

Sapei, L., Hwa, L. (2014). Study on the kinetics of vitamin $\mathrm{C}$ degradation in fresh strawberry juices. Procedia Chem., 9, 62-68.

Schwartz, S. J., Lorenzo, T. V. (2014). Chlorophyll stability during continuous aseptic processing and storage. J. Food Sci.,56,4,1059-1062.https://doi.org/10.1111/j.1365-2621. 1991.tb14641.x
Senphan, T., Yakong, N., Aurtae, K., Songchanthuek, S., Choommongkol, V., Fuangpaiboon, N., ..., Yarnpakdee, S. (2019). Comparative studies on chemical composition and antioxidant activity of corn silk from two varieties of sweet corn and purple waxy corn as influenced by drying methods. FABJ, 7(3), 64-80.

Sogi, D. S., Siddiq, M., Dolan, K. D. (2015). Total phenolics, carotenoids and antioxidant properties of Tommy Atkin mango cubes as affected by drying techniques. LWT - Food Sci. Technol., 62(1), 564-568.

Sunjka, P., Rennie, T., Beaudry, C., Raghavan, G. (2014). Microwave-convective and microwave-vacuum drying of cranberries: A comparative study. Drying Technol., 22(5), 1217-1231. https://doi.org/10.1081/ DRT-120038588

Tonon, R. V., Freitas, S. S., Hubinger, M. D. (2011). Spray drying of açai (Euterpe oleraceae mart.) juice: effect of inlet air temperature and type of carrier agent. J. Food Process. Preserv., 35(5), 691-700. https://doi. org/10.1111/j.1745-4549.2011.00518.x

Wan Omar, W. H., Sarbon, N. M. (2016). Effect of drying method on functional properties and antioxidant activities of chicken skin gelatin hydrolysate. J. Food Sci. Technol., 53(11), 3928-3938.

Wong, C. W., Pui, L. P., Ng, J. M. L. (2015). Production of spray dried Sarawak pineapple (Ananas comosus) powder from enzyme liquefied puree. Int. Food Res. J., 22(4), 1631-1636. 